\title{
The Influence of Family Structure on Academic Achievement in the Kwabre East Municipal Area, Ghana
}

\author{
David Anim Mante, Li Maosen, Kennedy Oduro Aboagye, Emmanuel Nana Kwesi Ofori Darko \\ School of Teacher Education, Huzhou University, Huzhou, China \\ Email: Jasonmante2018@yahoo.com,Ims791013@163.com,Kennedabs360@gmail.com,nkwesi55@gmail.com
}

How to cite this paper: Mante, D. A., Maosen, L., Aboagye, K. O., \& Darko, E. N. K. O. (2021). The Influence of Family Structure on Academic Achievement in the Kwabre East Municipal Area, Ghana. Open Journal of Social Sciences, 9, 220-242. https://doi.org/10.4236/jss.2021.912015

Received: November 6, 2021

Accepted: December 11, 2021

Published: December 14, 2021

Copyright $\odot 2021$ by author(s) and Scientific Research Publishing Inc. This work is licensed under the Creative Commons Attribution International License (CC BY 4.0).

http://creativecommons.org/licenses/by/4.0/

\begin{abstract}
This study focused on the influence of family structure on academic achievement in the Kwabre East Municipal Area. This study is guided by three objectives, namely to determine the families' roles in the academic achievement of senior high school students, to identify the challenges to the adequate performance of families' roles in the academic achievement of senior high school students and to investigate the influence of family structure on academic achievement of senior high school students in the Kwabre East Municipal Area. This study is a cross-sectional study where data were collected from 363 students in the Kwabre East Municipal. The data collection instrument was a structured questionnaire. The data collected were analyzed descriptively and quantitatively. Pearson Correlation Coefficient is used to establish the relationship between family structure and academic achievement of the respondents. The majority of the respondents disagreed that parents give school authorities health information about wards and academic histories. The parent does not support their wards in-home learning. Parents, however, support ICT learning in the schools and attend school programs such as an anniversary. Financial hardship was a significant challenge for the effective involvement of parents in the academic achievement of students. There is a significant strong positive correlation between parental roles in education and students' academic achievement. Parents should be made aware and encouraged to provide vital information, such as their wards' health information and academic history to school authorities. Parents should be made aware and encouraged to ensure their wards do their assignments. Parents should be encouraged to provide their children with required learning materials.
\end{abstract}

\section{Keywords}

Family Structure, Academic Achievement 


\section{Introduction}

Education is inevitable in human development since knowledge and talents are developed through education, making people fit nicely into every society. The fundamental goal of all education is to generate a positive change in the student's behavior. Stakeholders in education include government and its agencies, the family and the communities. According to Merriam-Webster Dictionary (2018), the family is the basic unit in society, traditionally consisting of two parents rearing their children or a group of individuals living under one roof and usually under one head. Family can be nuclear, extended family, step/blended family, single-parent family, adopted family and foster family and the contribution towards a child's education mostly depends on the type of family structure the child belongs to (Meleen, 2019). This makes parents very important in the academic achievement of children.

Academic achievement compares individual students' performance assessment scores from one year to the next, aggregated to the school level. Students' academic achievement is affected by many factors such as socioeconomic status, supportive teachers, student motivation, and language competency. However, the two most important factors are supportive school and classroom climate and family involvement (Collins et al., 2010). According to Epstein et al. (2009), the family plays an essential role in their children's academic achievement. These roles include parenting, communication, volunteering, learning at home, decision-making and collaboration. Parenting involves child upbringing from childhood to adolescence and adulthood, while communication involves giving information about the child to the school. Volunteering involves supporting school projects and development; learning at home involves assisting the child to learn at home and do all assignments, whiles collaboration involves partnering teachers and the schools to initiate activities that enhance child growth and development (Epstein et al., 2009).

In Ghana, every family wants its wards to perform academically well. However, economic pressure, among others, makes families less involved in their children's academic activities. This was made known in a survey done in the district where it was discovered that most families do communicate vital information such as children health status and educational history to school authorities from to time; volunteer to support school programs, support student excursions and ICT learning in the schools; help their children with their home learning and discuss their children's academic performances with teachers.

World Bank (2000) indicated that the extent to which families are involved in a child's education ultimately influences the child's academic achievement. In this view, this study assesses the influence of family structure on students' academic achievement in the Kwabre East Municipal Area.

In Ghana, family configurations are classified as nuclear, extended, step/blended, single-parent, adoptive, and foster. Family structures are crucial to some extent for children's academic progress. The family acts as a socializer and provides vi- 
tal support in financial, social, emotional, and educational support.

However, to the best of the researchers' knowledge and based on a literature review, preliminary studies have been sanctioned in Ghana to determine the effect of family structure on students' academic achievement in senior high schools. Thus, this study will examine the effect of family structure on academic attainment, focusing on the Kwabre East Municipal Area as a case study.

\subsection{Purpose of the Study}

This study sought to investigate the influence of family structure on the academic performance of senior high school students in the Kwabre East Municipal Area in the Ashanti Region of Ghana.

\subsection{Scope of the Study}

The study is limited to all second-cycle institutions in the Kwabre East Municipal Area, with the study's scope covering only the influence of family structure on academic achievement in the study area.

\subsection{Definitions of Terms}

The key terms in this study are family structure and academic achievement, and they are operationalized as follows;

Family structure refers to how families are segregated into nuclear family and extended family and their roles.

Academic achievement refers to how a child is performing under the course of study with time. Academic achievement is the average marks obtained in core subjects, namely Core Mathematics, Integrated Science and English Language, over one academic year.

\section{Literature Review}

\subsection{Concept of Academic Achievement}

According to the Maine Department of Education, academic achievement can be defined as comparing individual students' performance assessment scores from one year to the next, aggregated to the school level. Various schools establish their Satisfactory Academic achievement (SAP) standards as requested by the state. Satisfactory Academic achievement standards ensure that students are completing their coursework and, in some cases, ensure that scholarship students can continue to receive financial aid. Several factors contribute to successful academic achievement, such as socioeconomic status, supportive teachers, student motivation, language competency. However, the two most important factors are supportive school and classroom climate and family/parental involvement (Collins et al., 2010).

The management, norms, goals, teaching, relationships, culture, and learning experiences, collectively are the elements that create the climate of the school and classroom. Therefore, the classroom and school climate does not refer to 
only the physical structures of the school and well-organized classrooms. A supportive school and classroom creates a safe environment for students and encourages student-teacher, teacher parents relationships. Such an environment increases teachers' productivity and enhances students' understanding of lessons, leading to successful academic achievements.

Family/Parents' involvement implies that members of the family work with teachers of the school and their wards. Parent involvement may be in the form of assisting their children with homework, volunteering for school activities, supporting their wards during sports and other club activities, attending parent, teachers, and students' events. Students of such families mostly feel cared for by their parents, which aids them in focusing on their academic work, leading to higher academic performance.

Epstein et al. (2009) developed a theory that details parental involvement in their wards' academic outcomes. The theory outlines six types of parental involvement, which has remained the most helpful model that connects parents' involvement to academic achievement with three interrelated stakeholders (i.e., family, school, \& community). These six types of parental involvement, according to the theory, are Parenting, Communication, Volunteering, Learning at home, Decision-making and Collaborating with the community.

Another crucial factor that influences the academic achievement of students is motivation. Motivation can induce students to produce their best, whether intrinsic (the inner feeling to work harder) or extrinsic (rewards for achievement). With a good understanding of the goals of motivation, students can be encouraged to come out with their best. Students have to be encouraged to take up challenges rather than eluding from them and educate them to understand the purpose behind their school work and how it affects their academic achievement.

\subsection{Epstein's Theory of Family Roles in Academic Achievement}

Epstein et al. (2009) developed a theory that details parental involvement in their wards' academic outcomes. The theory outlines six types of parental involvement, which has remained the most helpful model that connects parents' involvement to academic achievement with three interrelated stakeholders (i.e., family, school, \& community). Theory depicts that an integrated interaction between the family, educators, and the community can promote the child's learning and development. According to Epstein et al. (2009), the six types of involvement are parenting, communication, volunteering, learning at home, decision-making, and community collaboration.

Parenting: The theory stipulates that the school should assist families to create a home atmosphere that supports their children as students. This implies that the school should provide families information that can improve their parenting skills, which will advance their children's development and create a living environment that helps students' academic achievement. This includes information on discipline, adolescence, child's health and nutrition, which will help parents 
of students execute their roles at each stage of their lives (Epstein, 2010; Herrell, 2011). Such information should be made available to all families, not families who attend school events only. Most often than not, families who do not attend school events need such information the most. Likewise, the school must incorporate information gathered from families about their homes into lessons taught. The theory stipulates that parenting type of involvement improves student discipline, increases school attendance, improves time for learning.

Communication: According to the theory, a two-way communication system should be established between the family/parents and the school concerning school programs and students' progress. The school has to develop several communication modes to transfer information between them and parents. These communication mediums may include PTA meetings, sending termly students' report cards to parents, telephone conversations, messaging/emails, social media (Newchurch, 2017). Establishing constant communication between these two stakeholders will provide an avenue to discuss students' progress and shortcomings mutually.

Oral or written communication increases parents' comprehension of school policies and procedures, taking into consideration extra support of the school (Epstein, 2013). The theory alludes that students who benefit from this communication link increase knowledge of their academic achievement, increase school attendance, improve their understanding of school rules and policies, heighten communication skills, and give them a sense of direction towards which study field to major.

Volunteering: This type of parent involvement encourages parents to support the school's mission and goals and learning processes in any capacity within their fields of proficiency. Therefore, the school must develop and create avenues to encourage families to participate in school events/activities. Volunteers could be tasked to be class parents, mentor students at open forums, convene school visits with established role models, participate in school collaborative work and join students during sporting activities (Mahuro \& Hungi, 2016). Volunteering grants schools and families to work together for the child's best interest academically. The theory postulates that students whose parents volunteer improve their communication skills with adults become exposed to life outside school, emulate volunteers and utilize the knowledge in their future life development.

Learning at home: The school can get parents involved by assisting them with materials and information about how to help children with curriculum-related subjects at home (Newchurch, 2017). These comprise assisting families to understand activities of school curriculum needed for academic achievement ion, devising means of informing parents on how to monitor children's practices and behaviors, educating parents on how to train their children on setting and achieving apt career goals, and how to choose best fitting school programs (Mahuro \& Hungi, 2016). Children are more likely to be actively involved in setting goals for academic success and planning post-secondary educational experiences when they are reassured by their parents (Epstein, 2010). The theory states that 
students who benefit from this attain improved test scores, improved homework completion, and develop a positive attitude towards schoolwork.

Decision-making: The fifth type of engagement demands parents' involvement in making decisions at the school, thus developing parent leaders and representatives (Piper, 2012). This implies that parents should be involved in the administration, governance, and decision-making roles. Parents can be involved through PTA and other parent organizations, councils, and advisory boards. Likewise, parents could be added to school management committees or assigned as school patrons or chairpersons (Mahuro \& Hungi, 2016). Being involved in the school governing board gives parents a voice in schools' affairs, policies, improvement and reforms. Students with this parental involvement have improved schooling and learning outcomes. Also, due to parents' representative (s), some policies are established on the students' behalf, satisfying their interests.

Collaborating with the community: This type of involvement identifies and combines resources bestowed in the community where schools and families reside to support students' academic achievement. The head (s) of the community may be included in any of the aforementioned parental engagements. Thus the school may provide families and students information on community health, cultural, recreational, social support, and programs that can benefit the child (Hall \& Quinn, 2014). Engagement in this practice can expose students to more learning opportunities; associate with individuals other than their parents, schoolmates, and teachers. Moreover, this can improve students' learning outcomes, serve as tapping talents for extra-curricular potentials, and apply knowledge obtained from school to the real world.

For this study, parental involvement in terms of parenting and communication was focused on. As identified by various researches, parenting (monitoring school attendance, enrolling children into preschool, organizing extra classes) and communication (interaction with the school about child's performance, receiving and checking students' report cards) affect a child's academic achievement. Therefore, this study sought to examine and confirm the validity of these findings from previous studies (Chohan \& Khan, 2010; Page, 2016; Kibaara \& Ndirangu, 2014).

\subsection{Empirical Review}

The empirical review establishes support from former studies by the researcher concerning this study, which sought to examine family's role in students' academic achievement. Different studies have established a relationship between the roles family plays in a child's education and their impact on academic achievement. These roles of the family have commonly been referred to as parental involvement in various studies. The study by Kibaara and Ndirangu (2014) sought to establish the effects of parental involvement on their children's academic achievement. The target population was 21 public schools in the Kieni-West sub-county of Nyeri county, Kenya. The researchers objected to: 1) examining the nature of parental involvement in their children's academic achievement, 2) 
revealing to what extent factors influencing parents' involvement contribute to their children's academic achievement, 3) examining teachers' views about parental involvement in the students' academic achievement. Participants in the study included students, parents, and teachers, who were gathered through stratified random sampling.

A purposive sampling method was used to sample from three students. Both qualitative and quantitative research techniques (triangulation method) were used in collecting and analyzing data. Thus, questionnaires were used to collect data from students and teachers, while a structured interview was utilized to gather data from parents, document analysis and researchers' observation. The study was formerly piloted in two schools within the geographical scope. The findings showed that $71.6 \%$ of parents monitored their wards' homework, and $84.7 \%$ participated in school events and activities. The majority of parent respondents $(92 \%)$ indicated that their involvement in their wards education is valuable to the teachers in helping with their academic achievement.

Moreover, almost all parent participants in the study (98.2\%) agreed that organized parental involvement programs could develop their relationship with their wards. Likewise, Newchurch (2017) examined the impact of parental involvement on student success: school and family partnership from the perspective of parents and teachers. A qualitative research approach was used for the study by implementing a narrative methodology to learn about the experiences expressed in lived and told stories of three parents and two teachers. The study is based on two of Epstein's six typologies of parental involvement, i.e., parenting and learning at home. A purposive sampling technique was used to gather three parents of 5th-grade students and two teachers of 5th-grade students as respondents.

The information retrieved from the sample aided in gathering data on their perceptions of school and family partnerships to answer the questions: 1) how are parents involved in their child's educational process? 2) how does parental involvement provide support to the child's school, family, and home-school connection? 3) what can parent stories tell us about parental involvement that is unobservable by the school and its effects on academic success? Data were collected through interview sessions in English only with respondents who contained open-ended questions. The responses during the interviews were recorded, transcribed and coded with concepts and themes.

The findings of the study were associated with three essential themes. These are 1) parenting skills and habits employed by parents are essential in a child's education and supports student success, 2) learning at home support skills and habits employed by parents is essential in a child's education and supports student success, 3) communication efforts are practical tools for promoting parental involvement. The majority of the respondents demonstrated that parenting skills benefit a child's education. Likewise, participants unanimously agreed that learning at home improves children's education. Conversely, not all parental and teacher communication pattern variances were due to what was observed by 
parents and teachers as necessities of the student. Mahuro and Hungi (2016) conducted a case study in Uganda's Iganga and Mayuge districts to confirm that parental participation improves academic achievement. With the aid of regression analysis, controlling individual, school, and household covariates, the finding was that parental participation motivates their wards towards more extraordinary academic achievements. The results showed that students' numeracy scores are increased significantly by 6 percent points upon a unit increase in parental participation through parenting and by 15 percent through communication types of involvement. Also, literacy scores increase significantly by 6 percent when there is a unit increase in parent participation through parenting and 12 percentage points through communication type of involvement. This was a cross-sectional survey of 2669 grade six and three public and private schools in rural Eastern Uganda. Using two of the Epstein parental involvement framework, the study assumed that parental participation through parenting and communication types of involvement would help children towards a positive academic achievement. The study collected both qualitative and quantitative data from the sample. A three-stage cluster sampling design was used to sample a target population comprising grade 6 and 3 English and Mathematics teachers, students, and parents of grades 6 and 3.

Page (2016) also examines parents' role in their children's academic achievement at a previously disadvantaged primary school in Cape Town. Using a qualitative research design, the study objected to answering these questions: 1) how does parental involvement influence their children's academic achievement? 2) What roles do educators expect parents to play in developing their ward's academic achievement? 3) Which factors enhance and hinder parental involvement across the phases of primary schooling? 4) How does parental involvement in children's academic achievement change over time as learners progress through the primary schooling phase? Three groups of respondents (parents, students, \& educators) were purposely sampled. The study used questionnaires together with individual semi-structured interviews to collect data from participants. The findings showed that parental involvement could positively influence their wards' academic achievement at the primary school phase. The majority of parent respondents attributed parental involvement to home-based activities rather than school-based involvement. Nevertheless, parent participants involved in their wards' schooling produced stronger academic achievers than those less involved. Learner participants with relatively weak scholastic achievement reported minimal homework assistance from parents and vice versa. Subsequently, average and strong scholastic achievement learners reported that their parents encouraged them to read, and vice versa. The study identified that communication between parents and their wards and between parents and educators is a factor that could hinder parental involvement. Likewise, a welcoming atmosphere at the school may also be considered as a factor. The educator participants indicated that parental involvement had a positive effect on the students' academic 
achievement. However, it was evident that parental support declined as learners progressed from one phase of schooling to another. In the city of Almaty, Kussainov et al. (2014) investigated family situations as a factor in students' academic achievement. The study's objective was to figure out how the typology of family upbringing influences the child's success as a learner and his academic achievement. The typology of family captured the upbringing capacities of the family as a group. A questionnaire was used to collect data from 723 grade 8 \& 9 students from a Kazakh and a Russian school from each of the 7 districts of Almaty. The questions covered the organization of learning activities at home, subject preferences, self-esteem and values, estimation of students of their family environment, educational opportunities, and academic achievement. The questionnaire contained open-ended questions, which allowed students to define their perspective on the problem and thus detailed the analysis results. Family environment was deemed the main determinant of the emotional sphere of a person, his moral outlook and ideological upbringing. The study's findings depicted that family conditions (social status, occupation, educational level of parents) had no significant impact on student's academic achievement. However, family support is a major factor that helps to create an atmosphere that forms a positive attitude towards school and learning. There was no significant difference in the achievement of positive educational results by students from complete and incomplete families. Moreover, Chohan and Khan (2010) examined the impact of parental support on the academic performance and self-concept of the student in Rawalpindi City. The data analysis showed that 53 percent of students had their parents arrange some tuition for their help. $29 \%$ noted that their parents compelled their elder siblings to help. Moreover, $18 \%$ stated that their parents themselves guide them in academic matters. 120 students reported that they had no kind of support from parents or any other family member. The results revealed that parents' contribution to their children's education has a consistent and positive effect on academic achievement and self-concept. This was a descriptive and quantitative study. The population target for the study was grade 4 public school students. The study aimed at examining the relationship between academic achievement and educational support provided to the child at home, also, to establish the effect of this support on a child's self-concept. The results from a sample of 305 urban primary \& elementary students were analyzed based on their annual school result report and also by using a self-concept scale. Students' self-concept was measured the month before the annual school examination and one month after the annual results announcement. According to $\mathrm{Mu}-$ thoni (2013), there is a positive association between students' academic performance and family size, parents' financial status, educational level, and marital status. The data analysis informed that marital status does not significantly explain students' academic performance; however, the type of family (conflictive or cohesive) influenced academic performance. Moreover, only 7 percent of students' academic performance would be explained by parents' educational level. The 
study evaluated the relationship between family backgrounds on students' academic performance in the suburb of Kenya. Family backgrounds relating to parental marital status, family financial status, parental educational level and family size were considered for the study. Using a descriptive research design, the study targeted 1081 students and parents, respectively. A sample of 338 was drawn out of the population using a stratified random sampling method. Researchers collected data via questionnaires for parent participants and utilized interviews for students. Data collected were analyzed through qualitative and quantitative mediums.

Recently, Li and Qiu (2018) studied how family background affects children's academic achievement early. The study proposes two ways through which family influences the wards' academic performance. These are: 1) parents compete for high-quality educational opportunities for their children, which may lead to better academic performance, 2) parenting behavior and educational support for their wards could influence the child's learning habits, which may affect the academic performance. Collectively, the researchers termed these key factors (differences in educational opportunities, child's learning behavior, \& parental educational involvement) as family socioeconomic status.

Secondary data was used and collected from the Chinese Family Panel Studies 2010 baseline survey (Ma et al., 2019). This was a survey of 14,960 households of the various parts of China, gathering data via questionnaires. The three questionnaires for each household were tailored as family questionnaire, adult (age 16 and above) questionnaire, and children's (age 10 - 15) questionnaire. The study purposely sampled 2750 cases for the study. The data were analyzed using multiple regression. The findings revealed that their families' socioeconomic status influences urban students' academic performance more than rural students. Precisely, socioeconomic status explained $20.8 \%$ of the difference in academic performance of urban students, while it explained $6.4 \%$ of the difference of rural students. Moreover, family background has significant urban-rural differences in the purchase of educational services. Lastly, the academic achievements of rural students are explained mainly by their learning behavior, which is higher than urban students.

\section{Methodology}

\subsection{Research Design}

This study is a cross-sectional study where primary data were collected from students in selected senior high schools in the Kwabre East Municipal Area. Based on the data collected and the nature of the study, this study employed a quantitative research design.

This study also employed both descriptive and correlational designs. The descriptive design describes the phenomena precisely in the way they exist to demonstrate the reality of a situation, and also, correlational design helps establish the relationship between two variables. Thus, the study could determine the 
relationship between family structure and students' academic achievements with a correlational design.

\subsection{Study Population}

The study's target populations are form two and three students in senior high schools in Kwabre East Municipal Area. Form two and three were considered in this study because students had not written any seminal examination; hence, their academic achievement could not be obtained.

\subsection{Sampling Procedure}

This study adopted three sampling techniques, namely convenience sampling, purposive sampling and simple random sampling. Under the convenience sampling, the study employed two criteria for selecting senior high schools in the district. Purposive sampling was used to select respondents who have been in the school for at least a year (SHS 2 and SHS3).

\subsection{Data Collection Instrument}

The main instrument used was questionnaires to collect all students' primary data. This study used a structured questionnaire because it helps collect standardized data, code data for statistical analysis, and collect data at a cheaper administration cost (Bryman, 2014).

\subsection{Data Collection Procedures}

This study collected all primary data in February 2021. Permission was sought from the schools before administering questionnaires (online). Mobile phone tablets were provided in the schools where students pass by to fill the online questionnaire in their free time. Assistance was given to respondents who had challenges filling in questionnaires to be. This helped to speed up the data collection process. Participation in the study was not compulsory, and all respondents were briefed about the purpose of the study and assured of confidentiality and anonymity.

\section{Results and Discussions}

\subsection{Sex of Respondents}

The socio-demographic characteristics of the respondents considered in this study were sex, as shown in Table 1 .

Table 1. Socio-demographic characteristics of respondents $(\mathrm{N}=363)$.

\begin{tabular}{cccc}
\hline Variables & Categories & Frequency & Percentage \\
\hline \multirow{2}{*}{ Sex } & Male & 166 & 45.8 \\
& Female & 197 & 54.2 \\
\hline
\end{tabular}

Source: Field Data (2021). 
Table 1 shows that females dominated with 197 (54\%) and 166 (46\%) males. The result in Table 1 shows that female students dominated male students. This suggests that female students outnumbered the male students in Senior High Schools in the Kwabre East Municipal Area. According to the 2020 Population and Housing Census, females outnumber males in Ghana (GSS, 2010). Moreover, females are given more placement opportunities in Senior High Schools than males, which is done to close the educational gap. Parents are more concerned about the welfare of their adolescent daughters than adolescent sons because of their vulnerability. This suggests that more parents would be willing to be involved in their children's education in the Kwabre East Municipal Area.

\subsection{Roles of Family in Academic Achievement of Students}

This section of the study focused on research question one "What roles do families play in the academic achievement of senior high school students in the Kwabre East Municipal Area? This study addressed this question using the Epstein (2009) Model of Family Roles in Academic achievement. The responses provided by the students on the roles of their families (parents) in their academic achievement are summarized in Table 2.

\section{Communication Role of Family}

The results in the Table 2 show that 27 (7.4\%) of the respondents strongly disagreed, 119 (32.8\%) disagreed, 72 (19.8\%) were neutral, whiles 118 (32.5\%) agreed, and the remaining 27 (7.4\%) strongly agreed that parents give information about their children's health to his/her teachers. The health of children is an indicator of academic excellence, and health status changes with time. Therefore, parents are to furnish educational authorities with the health status of their children from time to time, especially when the child is sick or seriously injured. This information would help teachers and other agents in school to effectively and efficiently relate with the child. However, a majority (60\%) of the respondents who are student sex pressed disagreement that parents give health information about them their teachers or school authorities.

From Table 2, 64 (17.6\%) of the respondents strongly disagreed, 100 (27.5\%) disagreed, 109 (30.0\%) were neutral, 63 (17.4\%) agreed, and 27 (7.4\%) strongly agreed that parents give information about their children's educational history to his/her teachers or school authorities. Information on the academic history of students is essential in teaching and learning. This is because some students are slow learners whiles others are fast learners, and this information would help school authorities better teach the children based on the children's learning abilities. However, a majority (75.1\%) of the students' respondents believed that parents did not provide this information to school authorities.

\section{Volunteering Role of Family}

Table 2 further shows that 27 (7.4\%) of the respondents strongly disagreed, 64 (17.6\%) disagreed, 190 (52.3\%) were neutral, 54 (14.9\%) agreed, and 28 (7.7\%) strongly agreed that parents raise funds to support school activities. This implies 
Table 2. Families' roles in academic achievement of senior high school students in the Kwabre east municipal area.

\begin{tabular}{|c|c|c|c|c|c|c|}
\hline $\begin{array}{c}\text { Families' role } \\
\text { variables }\end{array}$ & Statements & $\begin{array}{l}\text { Strongly } \\
\text { disagree }\end{array}$ & Disagree & Neutral & Agree & $\begin{array}{c}\text { Strongly } \\
\text { Agree }\end{array}$ \\
\hline \multirow{2}{*}{ Communication } & $\begin{array}{l}\text { Parents give } \\
\text { information about } \\
\text { their children's } \\
\text { health to his/her } \\
\text { teachers }\end{array}$ & $\begin{array}{c}27 \\
(7.4)\end{array}$ & $\begin{array}{c}119 \\
(32.8)\end{array}$ & $\begin{array}{c}72 \\
(19.8)\end{array}$ & $\begin{array}{c}118 \\
(32.5)\end{array}$ & $\begin{array}{c}27 \\
(7.4)\end{array}$ \\
\hline & $\begin{array}{l}\text { Parents give } \\
\text { information about } \\
\text { their children's } \\
\text { educational history } \\
\text { to his/her teachers }\end{array}$ & $\begin{array}{c}64 \\
(17.6)\end{array}$ & $\begin{array}{c}100 \\
(27.5)\end{array}$ & $\begin{array}{c}109 \\
(30.0)\end{array}$ & $\begin{array}{c}63 \\
(17.4)\end{array}$ & $\begin{array}{c}27 \\
(7.4)\end{array}$ \\
\hline \multirow{4}{*}{ Volunteering } & $\begin{array}{l}\text { Parents raise funds } \\
\text { to support school } \\
\text { activities }\end{array}$ & $\begin{array}{c}27 \\
(7.4)\end{array}$ & $\begin{array}{c}64 \\
(17.6)\end{array}$ & $\begin{array}{c}190 \\
(52.3)\end{array}$ & $\begin{array}{c}54 \\
(14.9)\end{array}$ & $\begin{array}{c}28 \\
(7.7)\end{array}$ \\
\hline & $\begin{array}{l}\text { Parents support } \\
\text { excursions }\end{array}$ & $\begin{array}{c}18 \\
(5.0)\end{array}$ & $\begin{array}{c}73 \\
(20.0)\end{array}$ & $\begin{array}{c}173 \\
(47.7)\end{array}$ & $\begin{array}{c}90 \\
(24.8)\end{array}$ & $\begin{array}{c}9 \\
(2.5)\end{array}$ \\
\hline & $\begin{array}{l}\text { Parents support } \\
\text { ICT learning in } \\
\text { the schools }\end{array}$ & $\begin{array}{c}27 \\
(7.4)\end{array}$ & $\begin{array}{c}99 \\
(27.3)\end{array}$ & $\begin{array}{c}83 \\
(22.9)\end{array}$ & $\begin{array}{c}145 \\
(39.9)\end{array}$ & $\begin{array}{c}9 \\
(2.5)\end{array}$ \\
\hline & $\begin{array}{l}\text { Parents attend } \\
\text { school } \\
\text { programmes }\end{array}$ & $\begin{array}{c}0 \\
(0.0)\end{array}$ & $\begin{array}{c}46 \\
(12.7)\end{array}$ & $\begin{array}{c}99 \\
(27.3)\end{array}$ & $\begin{array}{c}191 \\
(52.6)\end{array}$ & $\begin{array}{c}27 \\
(7.4)\end{array}$ \\
\hline \multirow[b]{2}{*}{$\begin{array}{l}\text { Home } \\
\text { learning }\end{array}$} & $\begin{array}{l}\text { Parents help their } \\
\text { children with } \\
\text { home works }\end{array}$ & $\begin{array}{c}28 \\
(7.7)\end{array}$ & $\begin{array}{c}54 \\
(14.9)\end{array}$ & $\begin{array}{c}145 \\
(39.9)\end{array}$ & $\begin{array}{c}82 \\
(22.6)\end{array}$ & $\begin{array}{c}54 \\
(14.9)\end{array}$ \\
\hline & $\begin{array}{l}\text { Parents take their } \\
\text { children to places } \\
\text { of tourist attractions } \\
\text { during vacations }\end{array}$ & $\begin{array}{c}46 \\
(12.7)\end{array}$ & $\begin{array}{c}92 \\
(25.3)\end{array}$ & $\begin{array}{c}135 \\
(37.2)\end{array}$ & $\begin{array}{c}81 \\
(22.3)\end{array}$ & $\begin{array}{c}9 \\
(2.5)\end{array}$ \\
\hline \multirow{4}{*}{ Collaborations } & $\begin{array}{l}\text { Parents provide } \\
\text { learning materials } \\
\text { for their children }\end{array}$ & $\begin{array}{c}0 \\
(0.0)\end{array}$ & $\begin{array}{c}37 \\
(10.2)\end{array}$ & $\begin{array}{c}63 \\
(17.4)\end{array}$ & $\begin{array}{c}163 \\
(44.9)\end{array}$ & $\begin{array}{c}100 \\
(27.5)\end{array}$ \\
\hline & $\begin{array}{l}\text { Parents discuss } \\
\text { academic activities } \\
\text { of students with } \\
\text { teachers }\end{array}$ & $\begin{array}{c}11 \\
(3.0)\end{array}$ & $\begin{array}{c}84 \\
(23.1)\end{array}$ & $\begin{array}{c}129 \\
(35.5)\end{array}$ & $\begin{array}{c}102 \\
(28.1)\end{array}$ & $\begin{array}{c}37 \\
(10.2)\end{array}$ \\
\hline & $\begin{array}{l}\text { Parents request } \\
\text { for extra classes } \\
\text { for students }\end{array}$ & $\begin{array}{c}0 \\
(0.0)\end{array}$ & $\begin{array}{c}45 \\
(12.4)\end{array}$ & $\begin{array}{c}117 \\
(32.2)\end{array}$ & $\begin{array}{c}174 \\
(47.9)\end{array}$ & $\begin{array}{c}27 \\
(7.4)\end{array}$ \\
\hline & $\begin{array}{c}\text { Parents engage } \\
\text { teachers on special } \\
\text { subjects like Science } \\
\text { and Mathematics }\end{array}$ & $\begin{array}{c}0 \\
(0.0)\end{array}$ & $\begin{array}{c}100 \\
(27.5)\end{array}$ & $\begin{array}{c}118 \\
(32.5)\end{array}$ & $\begin{array}{c}127 \\
(35.0)\end{array}$ & $\begin{array}{c}18 \\
(5.0)\end{array}$ \\
\hline
\end{tabular}




\section{Continued}

$\begin{array}{cccccc}\begin{array}{c}\text { Parents are involved } \\ \text { in the selection }\end{array} & 0 & 37 & 72 & 182 & 72 \\ \text { textbooks for their } & (0.0) & (10.2) & (19.8) & (50.1) & (19.8) \\ \text { students } & & & & & \end{array}$

Source: Field Data (2021); Figures outside the parenthesis are frequencies, and those in the parenthesis are their respective percentages.

that most (77.3\%) respondents expressed disagreement that parents raise funds to support school projects.

Fundraising in support of school building projects largely depends on the income level of the parents or guardians. However, in the Kwabre East Municipal Area, most parents are traders and farmers. Incomes of farmers are low with significant fluctuations in the year. Parents may not raise enough funds to support their children's school projects and academic achievement given farmers' low levels and fluctuating incomes. The outcome of this study is consistent with Eyiuche \& Chika (2014) that there is a low extent of parental support for schools' ICT integration in the curriculum. Eyiuche \& Chika (2014) explained that low parental involvement in ICT-Curriculum integration is likely to hinder the schools and their students from using ICT in curriculum delivery.

Results in Table 2 again indicates that 18 (5.0\%) of the respondents strongly disagreed, 73 (20.0\%) disagreed, 173 (47.7\%) were neutral, whiles the remaining $90(24.8 \%)$ agreed, and $9(2.5 \%)$ strongly agreed that parents support excursions or educational field trips. This implies that the majority (72.8\%) of the respondents expressed disagreement that parents support excursions of educational field trips.

Table 2 further indicates that 27 (7.4\%) of the respondents strongly disagreed, 99 (27.3\%) disagreed, 83 (22.9\%) neutral, and 145 (39.9\%) agreed, whiles the remaining $9(2.5 \%)$ strongly agreed that Parents support ICT learning in the schools. This implies that most (64.9\%) of the respondents agreed that parents support ICT learning.

It is also observed from the table that $46(12.7 \%)$ of the respondents disagreed, 99 (27.3\%) were neutral, 191 (52.6\%) agreed, and 27 (7.4\%) strongly agreed that parents attend school programs. This implies that the majority (60\%) of the respondents agreed that Parents attend school programs.

\section{Home Learning}

Table 2 further revealed that 28 (7.7\%) of the respondents strongly disagreed, 54 (14.9\%) agreed, 145 (39.9\%) were neutral, 82 (22.6\%) agreed, and 54 (14.9\%) strongly agreed that parents help their children with home works. This indicates that the majority $(62.5 \%)$ of the respondents expressed disagreement that parents help their children with home works. Parental support of home learning of their children requires two key things: the parents' educational attainment (especially the mother) and secondly time schedules of the parents (especially the mother). Educated mothers who most often stay at homes (less busy and less 
occupied by work) can efficiently and effectively support their children to do homework or take them on educative excursions during vacations. However, most parents, though they have been to school, have lower educational attainment. Most dropped out of school after secondary education, with few having first-degree education. This implies that most parents (especially mothers) in the Kwabre East Municipal Area do not have what it takes to support their children in home learning. The overall scoring on home learning as a form of parental involvement in children's education was neutral.

Table 2 further showed that $46(12.7 \%)$ of the respondents strongly disagreed, 92 (25.3\%) disagreed, 135 (37.2\%) were neutral, 81 (22.3\%) agreed, and 9 (2.5\%) strongly agreed that parents take their children to places of tourist attractions during vacations. This implies that the majority $(75.2 \%)$ of the respondents expressed disagreement that parents take their children to tourist attractions during vacations. UNICEF (2009) states that parents should take their children to places of interest, such as zoos, museums, local craft centers, shopping, and market places for effective learning. UNICEF (2009) explained that excursion broadens children's minds and helps children learn by practical approach or learning by seeing, which helps students easily remember what is learned. This implies that these activities support a child's learning effort, enhancing performance and increasing the educational horizons. Parents to neglect these areas might limit effective learning and academic achievement among students (UNICEF, 2009).

The results in Table 2, however, show that $37(10.2 \%)$ of the respondents disagreed, 63 (17.4\%) were neutral, whiles 163 (44.9\%) agreed, and the remaining $100(27.5 \%)$ strongly agreed that parents discuss academic activities of students with teachers. This means that most (72.4\%) respondents agreed that parents discuss students' academic activities with teachers.

\section{Collaborative Role of Family}

From Table 2, $11(3.0 \%)$ of the respondents strongly disagreed, $84(23.1 \%)$ disagreed, 129 (35.2\%) were neutral, 102 (28.1\%) agreed, and 37 (10.2\%) strongly agreed that parents provide learning materials for their children. This means that the majority (61.6\%) of the respondents expressed disagreement that parents provide learning materials for their children. Table 2 again indicates that $100(27.5 \%)$ of the respondents disagreed, $118(32.5 \%)$ were neutral, whiles the remaining 127 (35.0\%) agreed and 18 (5.0\%) strongly agreed that Parents engage teachers on particular subjects like Science and Mathematics. This also indicates that the majority $(60.0 \%)$ of the respondents expressed disagreement parents engage teachers in special subjects like Science and Mathematics.

Table 2 further shows that $45(12.4 \%)$ of the respondents disagreed, 117 (32.2\%) were neutral, $174(47.9 \%)$ agreed, and $27(7.4 \%)$ strongly agreed that parents requested extra classes for students. This implies that most (55.3\%) respondents agreed that parents request extra classes for students. The table indicates that $37(10.2 \%)$ of the respondents disagreed, $72(19.8 \%)$ were neutral and 182 (50.1\%) agreed, whiles the remaining 72 (19.8\%) strongly agreed that Parents are 
involved in the selection of textbooks for their students. This implies that the majority (69.9\%) of the respondents agreed that parents are involved in selecting textbooks for their students.

\subsection{Challenges to Effective Performance of Families' Roles in Academic Achievement}

This section of the study focused on research question two, "To identify the challenges to the effective performance of families' roles in the academic achievement of senior high school students in the Kwabre East Municipal Area." This study selected key factors that hinder parental involvement in education through literature review and asked the respondents to indicate their extent of agreement or disagreement to each. The statements were in five Likert scales ranging from strongly disagree (1) to agree (5) strongly. The responses obtained are summarized in Table 3.

The results in the Table 3 shows that 27 (7.4\%) of the respondents strongly disagreed, 37 (10.2\%) disagreed, 72 (19.8\%) were neutral, whiles 155 (42.7\%) agreed, and the remaining $72(19.8 \%)$ strongly agreed that financial resource of the parents hinders the academic achievement of students in senior high schools.

Table 3. Challenges to the effective performance of families' roles in the academic achievement of senior high school students in the Kwabre East Municipal area.

\begin{tabular}{|c|c|c|c|c|c|}
\hline Statements & $\begin{array}{l}\text { Strongly } \\
\text { disagree }\end{array}$ & Disagree & Neutral & Agree & $\begin{array}{l}\text { Strongly } \\
\text { agree }\end{array}$ \\
\hline Financial resource of the parents & $\begin{array}{c}27 \\
(7.4)\end{array}$ & $\begin{array}{c}37 \\
(10.2)\end{array}$ & $\begin{array}{c}72 \\
(19.8)\end{array}$ & $\begin{array}{c}155 \\
(42.7)\end{array}$ & $\begin{array}{c}72 \\
(19.8)\end{array}$ \\
\hline Time of parents & $\begin{array}{c}36 \\
(9.9)\end{array}$ & $\begin{array}{c}27 \\
(7.4)\end{array}$ & $\begin{array}{c}101 \\
(27.8)\end{array}$ & $\begin{array}{c}118 \\
(32.5)\end{array}$ & $\begin{array}{c}81 \\
(22.3)\end{array}$ \\
\hline Educational attainment of parents & $\begin{array}{c}9 \\
(2.5)\end{array}$ & $\begin{array}{c}46 \\
(12.7\end{array}$ & $\begin{array}{c}91 \\
(25.1)\end{array}$ & $\begin{array}{c}181 \\
(49.9)\end{array}$ & $\begin{array}{c}36 \\
(9.9+)\end{array}$ \\
\hline $\begin{array}{l}\text { The distance to the } \\
\text { school/location of the school }\end{array}$ & $\begin{array}{c}0 \\
(0.0)\end{array}$ & $\begin{array}{c}81 \\
(22.3)\end{array}$ & $\begin{array}{c}90 \\
(24.8)\end{array}$ & $\begin{array}{c}165 \\
(45.5)\end{array}$ & $\begin{array}{c}27 \\
(7.4)\end{array}$ \\
\hline The attitudes of the teachers & $\begin{array}{c}73 \\
(20.1)\end{array}$ & $\begin{array}{c}145 \\
(39.9)\end{array}$ & $\begin{array}{c}54 \\
(14.9)\end{array}$ & $\begin{array}{c}82 \\
(22.6)\end{array}$ & $\begin{array}{c}9 \\
(2.5)\end{array}$ \\
\hline The attitudes of the headmaster & $\begin{array}{c}64 \\
(17.6)\end{array}$ & $\begin{array}{c}145 \\
(39.9)\end{array}$ & $\begin{array}{c}100 \\
(27.5)\end{array}$ & $\begin{array}{c}45 \\
(12.4)\end{array}$ & $\begin{array}{c}9 \\
(2.5)\end{array}$ \\
\hline Health status of parents & $\begin{array}{c}36 \\
(9.9)\end{array}$ & $\begin{array}{c}127 \\
(35.0)\end{array}$ & $\begin{array}{c}73 \\
(20.1)\end{array}$ & $\begin{array}{c}100 \\
(27.5)\end{array}$ & $\begin{array}{c}27 \\
(7.4)\end{array}$ \\
\hline Parent-child relationship & $\begin{array}{c}18 \\
(5.0)\end{array}$ & $\begin{array}{c}55 \\
(15.2)\end{array}$ & $\begin{array}{c}126 \\
(34.7)\end{array}$ & $\begin{array}{c}119 \\
(32.8)\end{array}$ & $\begin{array}{c}45 \\
(12.4)\end{array}$ \\
\hline Large family size & $\begin{array}{c}9 \\
(2.5)\end{array}$ & $\begin{array}{c}56 \\
(15.4)\end{array}$ & $\begin{array}{c}45 \\
(12.4)\end{array}$ & $\begin{array}{c}199 \\
(54.8)\end{array}$ & $\begin{array}{c}54 \\
(14.9)\end{array}$ \\
\hline Value parents place on education & $\begin{array}{c}9 \\
(2.5)\end{array}$ & $\begin{array}{c}118 \\
(32.5)\end{array}$ & $\begin{array}{c}65 \\
(17.9)\end{array}$ & $\begin{array}{c}153 \\
(42.1)\end{array}$ & $\begin{array}{c}18 \\
(5.0)\end{array}$ \\
\hline
\end{tabular}

Source: Field Data (2021); Figures outside parenthesis are frequencies, and those in the parenthesis are their respective percentages. 
This means that the majority (62.5\%) of the respondents agreed financial resource of the parents hinders the academic achievement of students in senior high schools.

From Table 3, 34 (9.9\%) of the respondents strongly disagreed, 27 (7.4\%) disagreed, 101 (27.8\%) were neutral, 118 (32.5\%) agreed, and 81 (22.3\%) strongly agreed that Time of parents hinders the academic achievement of students in senior high schools. This means that the majority (54.8\%) of the respondents agreed that parents' time hinders students' academic achievement in senior high schools. Parents are engaged mainly by the economic activities of parents (work) and household chores, and these and other engagements of parents prevent them from actively engaging in their children's educational activities. Most parents leave home early in the morning and return home late in the night, making them unable to supervise their children's home learning or attend school programs like PTA, where they could educate their children in the schools. This is consistent with Mufanechinaya's (2015) findings that parents face time constraints; hence, they are reluctant to be involved in their children's education.

Table 3 further shows that 9 (2.5\%) of the respondents strongly disagreed, 46 (12.7\%) disagreed, 91 (25.1\%) were neutral, 181 (49.9\%) agreed, and 36 (9.9\%) strongly agreed that the educational attainment of parents hinders the academic achievement of students in senior high schools. This implies that the majority (59.8\%) of the respondents agreed that parents' educational attainment hinders students' academic achievement in senior high schools. Educated parents could assist or effectively supervise their children's home learning, have a higher income to volunteer or collaborate with teachers to support their children, afford to buy all needed learning materials, and engage in decision-making through PTA. However, this study revealed that some parents have no formal education or very low educational attainment (up to secondary level). This suggests that most parents in the study area have low educational attainment, constraining them to be involved effectively and efficiently in educational activities, especially home learning of children in the Sekyere South.

\section{District}

Table 3 indicates that $81(22.3 \%)$ of the respondents disagreed, $90(24.8 \%)$ were neutral, whiles the remaining 165 (45.5\%) agreed, and 27 (7.4\%) strongly agreed that the distance to the school/location of the school is a barrier to the effective involvement of parents in the academic achievement of students. This also indicates that the majority (52.9\%) of the respondents agreed that the distance to the school/location is a barrier to effective participation of children's academic activities in school. The study revealed that most of the parents of the students live in their hometowns while their children are in boarding houses or hostels, thereby preventing most parents from supervising their children's academic activities.

The results in Table 3 further shows that 9 (2.5\%) of the respondents strongly disagreed, 56 (15.4\%) disagreed, 45 (12.4\%) were neutral, whiles 199 (54.8\%) agreed, and the remaining 54 (14.9\%) strongly agreed that large family size is a 
challenge to the effective performance of families' roles in the academic achievement of senior high school students. This means that the majority $(69.7 \%)$ of the respondents agreed that large family size is a challenge to the effective performance of families' roles in the academic achievement of senior high school students. Large family size increases the financial commitment of parents, making them financially overburdened. This situation constrains most parents from collaborating with the school or volunteering to support their children's academic achievement.

Table 3 again shows that 9 (2.5\%) of the respondents strongly disagreed, 118 (32.5\%) disagreed, 65 (17.9\%) were neutral, whiles 153 (42.1\%) agreed. The remaining $18(5.0 \%)$ strongly agreed that the value parents place on education is a challenge to the effective performance of families' roles in the academic achievement of senior high school students. This means that the majority (52.9\%) of the respondents agreed that the value parents place on education is a challenge to the effective performance of families' roles in the academic achievement of senior high school students.

Table 3 indicates that $73(20.1 \%)$ of the respondents strongly disagreed, 145 (39.9\%) disagreed, 54 (14.9\%) neutral, and $82(22.6 \%)$ agreed, whiles the remaining $9(2.5 \%)$ strongly agreed that attitudes of the teachers are a barrier to the effective involvement of parents in the academic achievement of students. This suggests that the majority (74.9\%) of the respondents expressed disagreement that the teachers' attitudes are a barrier to the effective involvement of parents in students' academic achievement. It is also observed from Table 3 that $64(17.6 \%)$ of the respondents strongly disagreed, 145 (39.9\%) disagreed, 100 (27.5\%) were neutral, $45(12.4 \%)$ agreed, and 9 (2.5\%) strongly agreed that the attitude of the headmasters is a barrier to the effective involvement of parents in the academic achievement of students. This implies that the majority (85\%) of respondents expressed disagreement that the attitude of the headmasters is a barrier to the effective involvement of parents in the academic achievement of students. This implies that the attitude of teachers and heads of schools is not a challenge to family roles in students' academic achievement.

Table 3 further revealed that 36 (9.9\%) of the respondents strongly disagreed, 127 (35.0\%) disagreed, 73 (20.1\%) neutral, 100 (27.5\%) agreed and $27(7.4 \%)$ strongly agreed that the health status of parents is a barrier to the effective involvement of parents in the academic achievement of students. This indicates that the majority (65\%) of the respondents expressed disagreement that parents' health status is a barrier to the effective involvement of parents in the academic achievement of students.

Table 3 again shows that 18 (5.0\%) of the respondents strongly disagreed, 55 (15.2\%) disagreed, 126 (34.7\%) were neutral, 119 (32.8\%) agreed, and 45 (12.4\%) strongly agreed that the parent-child relationship is a challenge to the effective performance of families' roles in the academic achievement of senior high school students. This implies that the majority (54.9\%) of the respondents expressed disagreement that the parent-child relationship is a challenge to the effective 
performance of families' roles in the academic achievement of senior high school students.

\subsection{Influence of Family Structure on Academic Achievement of Students}

The third and last research question was "what is the influence of family structure on academic achievement of senior high school students in the Kwabre East Municipal Area?" To address this question fully, the study first analyzed the academic achievement of students over two (first and second-year terminal reports of the selected 363 form two and three students). The academic achievement scores of the students are shown in Figure 1.

From Figure 1, results show that $31(8.5 \%)$ of the respondents had an average score between 65\% - 69\%, whiles the remaining 59 (16.3\%), 96 (26.4\%), 97 (26.7\%) 65 (17.9\%) and 15 (4.2\%) had an average scores 55\% - 59\%, 60\% - 64\%, $65 \%-69 \%, 70 \%-74 \%, 75 \%-79 \%$ respectively. The results show that most of the respondents sampled for this study had academic achievements between $65 \%$ - 69\% in their examinations. According to West African Examination Council, an examination score between $65 \%-69 \%$ is interpreted as credit. This indicates that most students obtained credit in their examinations conducted in their respective schools over the two years.

This study further used Pearson's Correlation Coefficient Matrix to establish the relation between the students' parental roles and academic achievement, and the results are summarized in Table 4.

The results in Table 4 show a significant strong positive correlation $(\mathrm{r}=$ $0.818^{\star *}$ ) between parental roles in education and students' academic achievement.

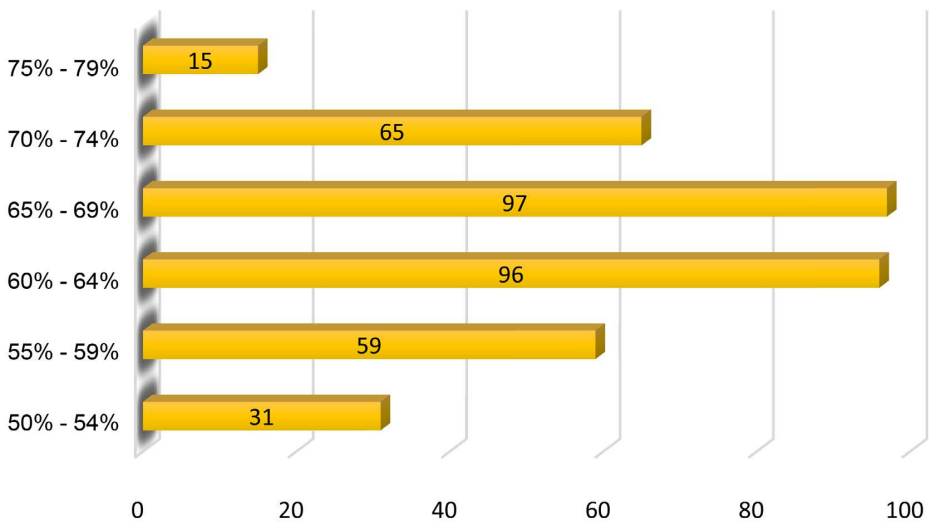

Figure 1. The academic achievement scores of the students. Source: Field Data (2021).

Table 4. Pearson's correlation coefficient matrix.

\begin{tabular}{ccc}
\hline & Students' academic achievement & Parental roles \\
\hline Students' academic achievement & 1.000 & $0.818^{\star *}$ \\
Parental roles & & 1.000
\end{tabular}

Source: Field Data (2021); ${ }^{* *}$ correlation is significant at the 0.01 (2-tailed). 
Therefore, as parents perform their roles effectively, students achieve higher academic achievement. However, as parents neglect their roles in education, students perform poorer in academic.

\section{Summary of Findings, Conclusions and Recommendations 5.1. Summary of Findings}

The summary of findings is grouped into three based on the research objectives as follows.

\subsubsection{Roles of Family in Academic Achievement of Students}

The study found that the majority (60\%) of the students' respondents expressed disagreement that parents give health information about them to their teachers or school authorities. The study further revealed that most (75.1\%) respondents believed that parents do not provide academic histories to school authorities. This study found out that the majority (77.3\%) of the respondents expressed disagreement that parents raise funds to support school projects and support student excursions or educational field trips.

However, this study revealed that parents support ICT learning in the schools and attend school programs such as an anniversary.

The study further found that parents do not help their children with homework and take them to tourist attractions during vacations. This study, however, found out that parents discuss the academic activities of students with teachers.

The study found that parents do not provide learning materials for their children and do not engage teachers in special subjects like Science and Mathematics. However, parents request extra classes for students and are involved in selecting textbooks for their children.

5.1.2. Challenges to Family's Roles in Academic Achievement of Students This study found out that financial hardship of the parents, less time for parents, lower educational attainment of parents, long distance to the school/location of the school, large family size, bad parents' perception of education and poor attitudes towards teachers and headteachers, the poor health status of parents are barriers to the effective involvement of parents in the academic achievement of students.

\subsubsection{Influence of Family Structure on Academic Achievement of Students}

This study realized that most respondents scored between 65\% - 69\% (credit) in the seminal examinations over the two years (2018 and 2019). The study found a significant strong positive correlation $\left(r=0.818^{* *}\right)$ between parental roles in education and students' academic achievement.

\subsection{Conclusions}

This study investigated the family structure and its influence on the academic achievement of senior high school students in the Kwabre East Municipal Area. 
The study, based on its findings, concludes as follows:

Firstly, this study concludes that parents have performed less than expected in their children's education to improve academic achievement. Most parents in Kwabre East Municipal Area do not provide health and academic records of their children to the school authorities, raise funds for projects at the school or student excursions or educational field trips, nor do they help their children with homework, take them to tourist attractions during vacations, nor do they provide learning materials for their children, nor do they engage teachers on specialized subjects such as science. This suggests that parents are shirking their responsibilities towards their children's education. This may be due to the implementation of free senior high schools in the Government of Ghana.

This is because most of the responsibilities hitherto were undertaken by parents are now performed directly by governments.

Secondly, this study concludes that parents face numerous challenges that prevent them from effectively performing their roles in their children's education. Some of the challenges include financial hardship coupled with large family size, less time for parents due to their engagement in economic activities, lower educational attainment, long distance to the school, bad parents' perception of educational outcome and poor attitudes towards teachers and headmasters, the poor health status of parents.

Thirdly, this study concludes that students' academic achievement and parental roles in education have a significant positive relationship. Thus, parental roles in education significantly influence students' academic achievement in the Kwabre East Municipal Area.

\subsection{Recommendations}

This study recommends improving parents' roles and academic achievement of senior high school students in Kwabre East Municipal Area based on the findings.

Parents should be made aware and encouraged to provide vital information such as their children's health information and academic history to school authorities. This information would help teachers and other staff know how to effectively deal with teaching students to help improve their performance in schools.

Parents should be encouraged to support school projects, and excursions, or educational field trips through the Parent-Teacher Association. Parents should be made aware and encouraged to ensure their wards do their assignments by their teachers or revise their notes when they are at home.

Parents should be encouraged by teachers and headmasters through Parent Teacher Association meetings to provide their wards with learning materials such as notebook and exercise books, textbooks, mathematical sets and pens. Access to learning materials would help students participate in all academic activities such as writing notes, exercise and tests, and revision after school. These 
would help improve the academic achievement of students.

Parents should be educated through Parent-Teacher Association on teachers' important roles in children's academic and moral upbringing. This would help parents to have a positive perception of the teacher, leading positive parent-teacher relationship.

\section{Conflicts of Interest}

The authors declare no conflicts of interest regarding the publication of this paper.

\section{References}

Bryman, A. (2014). June 1989 and Beyond: Julia Brannen's Contribution to Mixed Methods Research. International Journal of Social Research Methodology, 17, 121-131.

Chohan, B. I., \& Khan, R. M. (2010). Impact of Parental Support on the Academic Performance and Self Concept of the Student. Journal of Research and Reflections in Education, 4, 14-26.

Collins, D., Jordan, C., \& Coleman, H. (2010). An Introduction to Family Social Work (pp. 28-29). Brooks/Cole, Cengage Learning.

Epstein, J. L. (2010). School/Family/Community Partnerships: Caring for the Children We Share. Phi Delta Kappan, 92, 81-96. https://doi.org/10.1177/003172171009200326

Epstein, J. L. (2013). Ready or Not? Preparing Future Educators for School, Family, and Community Partnerships. Teaching Education, 24, 115-118. https://doi.org/10.1080/10476210.2013.786887

Epstein, J. L., Sanders, M. G., Sheldon, S., Simon, B. S., \& Salinas, K. C. (2009). School, Family and Community Partnerships. Corwin.

Eyiuche, O. R., \& Chika, O. Z. (2014). Science Education for Sustainable Development: A Need for Nigeria.

GSS (Ghana Statistical Service). (2010). 2010 Population and Housing Census.

Hall, N., \& Quinn, R. (2014). Parental Involvement at the High School Level: Parents' Perspectives. Journal of Ethnic and Cultural Studies, 1, 13-21. https://doi.org/10.29333/ejecs/9

Herrell, P. O. (2011). Parental Involvement: Parent Perceptions and Teacher Perceptions. Doctoral Dissertation, UMI No. 3462048.

Kibaara, T. M., \& Ndirangu, L. M. (2014). Parental Involvement in Their Children's Academic Achievement in Public Secondary Schools: A Case of Kieni-West Sub-County, Nyeri County-Kenya. International Journal of Education and Research, 2, 411-422.

Kussainov, A. K., Boulatbayeva, A. A., \& Shaumen, G. S. (2014). Family Situation as a Factor of the Academic Achievement of Students. International Journal of Humanities and Social Sciences, 4, 121-129.

Li, Z., \& Qiu, Z. (2018). How Does Family Background Affect Children's Educational Achievement? Evidence from Contemporary China. The Journal of Chinese Sociology, 5, 13. https://doi.org/10.1186/s40711-018-0083-8

Ma, X., Wang, Z., \& Liu, X. (2019). Progress on Catastrophic Health Expenditure in China: Evidence from China Family Panel Studies (CFPS) 2010 to 2016. International Journal of Environmental Research and Public Health, 16, 4775.

Mahuro, G. M., \& Hungi, N. (2016). Parental Participation Improves Student Academic 
Achievement: A Case of Iganga and Mayuge Districts in Uganda. Cogent Education, 3, Article ID: 1264170. https://doi.org/10.1080/2331186X.2016.1264170

Meleen, M. (2019). Pros and Cons of the Nuclear Family. https://family.lovetoknow.com

Muthoni, K. L. (2013). Relationship between Family Background and Academic Performance of Secondary Schools Students: A Case of Siakago Division, Mbeere North District, Kenya. Doctoral Dissertation, MA Thesis, University of Nairobi.

Newchurch, A. (2017). The Impact of Parental Involvement on Student Success: School and Family Partnership from the Perspective of Parents and Teachers.

Page, R. D. (2016). The Role That Parents Play in Their Children's Academic Achievement at a Previously Disadvantaged Primary School in Cape Town.

Piper, T. (2012). Using School Website to Support Parent Engagement. Leadership, 42, 36-38.

UNICEF. (2009). UNICEF Annual Report 2010.

World Bank. (2000). World Development Report 2000/2001: Attacking Poverty. The World Bank. 